\title{
After-hour trading influence on price discovery of Indian equity market for year 2017 and 2018
}

\author{
Meet Jignesh Shah ${ }^{*}$, Vaibhav Ajit Shrivastava ${ }^{2}$ \\ ${ }^{1}$ School of Petroleum Technology, Pandit Deendayal Petroleum University, Gandhinagar, Gujarat, ${ }^{2}$ Dept. of Information Technology, Sri \\ Ramaswamy Memorial Institute of Science and Technology, Chennai, Tamil Nadu, India \\ *Corresponding Author: Meet Jignesh Shah \\ Email: meet.26.1.97@gmail.com
}

\begin{abstract}
The paper examines the influence of after-hour trading on sixteen sector wise indices listed on National Stock Exchange of India Limited for year $2017 \& 2018$. We establish two independent conditions based on daily opening, closing, high \& low prices during market hours for indices \& listed index companies for each year. Our findings indicate that influence of after-hour trading on Indian equity market for year 2017 is higher than that of year 2018 based on individual listed companies performance under their respective sector wise index when the price of equity rises over previous market day in accordance with condition 1 . However, the study suggests that there is no clear indication for after-hour trading influence on Indian equity market between year 2017 \& 2018 when the equity price fell in comparison to previous market day in accordance to condition 2 .
\end{abstract}

Keywords: Price discovery, NIFTY, NSE, After-hour trading, After Market Order (AMO).

\section{Introduction}

\section{Market Timing of Equities Segment}

Trading on the equities segment in India takes place on all days of week (except Saturdays, Sundays and holidays declared on exchange in advance). After-hour trading is the period of time after the market closes when an investor can buy and sell securities outside of regular trading hours through computerized order matching systems called Electronic Markets. The market timings of equities segment in Indian Standard Time (IST) are: ${ }^{1}$

\section{Pre-open Session}

Order entry \& modification Open: 09:00 AM

Order entry \& modification Close: 09:08 AM

Order matching \& confirming trade: 09:08 AM to 09:15 AM

\section{Regular Trading Session}

Normal/ Limited Physical Market Open: 09:15 AM Normal/ Limited Physical Market Close: 03:30 PM

\section{Block Deal Session Timings}

Morning Block Deal Window: this window shall operate between 08:45 AM to 09:00 AM

Afternoon Block Deal Window: This window shall operate between 02:05 PM to 2:20 PM

The Closing Session is held between 03:40 PM and 04:00 PM (buy/sell orders in equity at market price.

\footnotetext{
$\overline{1}$ National Stock Exchange of India Limited, Equities Market Timings \& Holidays

After Market Order (AMO)

Call and Trade: 08:30

$\mathrm{AM}$ to 09:12 AM
}

With rising percentage of Internet Based Trading 2 (15.6\% of total trades on NSE) as a mode of trading the AMO executed online by large investors are bound to affect market opening price.

\section{Block Deal Session}

Extensive empirical tests which tend to support the efficiency of stock market have been carried out in the past (Tiwari et al. 2019) but recently a study concludes the impact of large orders have on electronic market (Zhang et al., 2019; Mugira et al., 2019). Block deal morning session occurring before regular trading session shall affect the market opening price. The following are key features of block trades executed on NSE.

\section{Reference Price}

For afternoon block deal window reference price shall be volume weighted average price (VWAP) of trade executed in the cash segment between 01:45 PM to 02:00 PM. Morning block deal window reference price for execution shall be previous day closing price of stock. If no trades are executed in the security in the cash segment between 01:45 $\mathrm{PM}$ to 02:00 PM time window then:

1. VWAP is based on trades executed in security between 09:00 AM to 01:45 PM shall be taken as reference price, or

2. In case VWAP is not available as per above, then the previous day's adjusted close price shall be considered as reference price.

a. Order size: Minimum order size for execution of trades in Block deal window shall be Rs. 100 million

b. Market orders are not allowed for Block deal session

c. The orders placed shall be within $\pm 1 \%$ of the applicable reference price in the respective windows. ${ }^{3}$

Online: 05:30 PM to 09:15 AM 


\section{After-hour Trading Risks}

1. Order Handling: All rules that apply to regular trading hours, do not apply to orders in after-hours trading. Also there is lack of uniformity between brokerage firms for placing and handling orders.

2. Lack of Liquidity: After hours generally witness less trading interest and less price competition, which may raise trading costs, increase uncertainty with respect to prevailing prices and make it difficult to execute trades.

3. Larger Quote Spreads: Rescued level to trading interest in after-hours results in wider spreads between the bid and ask price for a stock or no quotes at all.

4. Price Volatility: For stocks with limited trading activity, investors may find greater price fluctuations than they typically would find during regular trading hours

5. Requirements of Limit Orders: Many brokerage firms only accept limit orders during after-hours trading in order to protect investors from unexpectedly bad prices

6. Order Time Limit: Due to less regulation levied during after-hours trading, Investors need to constantly communicate with brokerage firms to carry forward their unexecuted orders during after-hour trading to regular trading hours or vice versa

7. Competition with Professional Traders: Individual investors should be aware that many of the after-hour traders are professional traders who have access to more information \& funds, changing after-hour market into oligopolistic market. ${ }^{4}$

\footnotetext{
${ }^{2}$ National Stock Exchange of India Limited, Cash Market- Modes of Trading, press release February 2019

${ }^{3}$ The Securities and Exchange Board of India (SEBI) vide letter MRD/DoP/SE/Cit- dated September 02, 2005 and CIR/MRD/DP/118/2017 dated October 26, 2017 for new block window introduction

${ }^{4}$ U.S. Security and Exchange Commission, Office of Investor Education and Advocacy, press release May 2011
}

\section{After-hour Trading Benefits}

Individual after-hours trades can contain more information than during the day because information asymmetry declines over the day, price changes are larger, reflect private information, and are less noisy before the opening than after the closing of market (Barclay \& Hendershott, 2004). Hence even low after-hour trading volume can generate significant price discovery. Family firms prefer regular market hours when they have an incentive through leakage of material, non-public information as the trend set forth is generally of short selling (Anderson et al., 2003). After-hours are preferred by family firms for public information announcement as it would benefit companies stock performance more during the next market day by taking advantage of the herd behaviour among investors.

\section{Convenience}

After-hour serves as mere extended trading time for some traders/ investors from regular trading time.

\section{Ability to React to News}

Any company announcement at different time from regular market hours allows investors/traders to still capitalise on this opportunity. This study has collected \& interpreted daily regular market data for year 2017 \& 2018 and attempted to account for how each company's stock price might have been influenced by reported company news and professional traders activity outside the regular market hours.

\section{Ability to Act More Quickly to Technical Signals}

Trading during after-hours can be very beneficial for technically-oriented traders using closing price and volume figures to calculate trading signals which are clearer in their indication due to less noise.

\section{Data}

We have included total sixteen sector wise indices listed on National Stock Exchange of India Limited. Each sector has its own index price representative of the cumulative performance of its components. Daily opening, closing, high $\&$ low price of components of each sector's index are collected from January 2, 2017 to December 29, 2017 for year 2017 and from January 1, 2018 to December 31, 2018 for year 2018 from database provided by NSE India Limited. Table $1 \& 2$ shows sector wise indices and number of components (listed companies on NSE) that fall under umbrella of each of the sector wise index. (A company can have listings in multiple sector wise index)

\section{Methodology}

The data obtained for conducting the research was done through web scrapping the data available on NSE online database using the language Python and its packages Selenium \& Beautiful soup. The data was further processed using Python \& Openpy excel. The data gathered is strictly used for research purpose only.

Below are the six conditions developed by using daily open, close, high \& low market price for each component's daily equity price for each year:

$O T>0.995(H Y)$ and $C T \leq 0.995(H T)$

$O T<0.995(L Y)$ and $C T \geq 0.995(L T)$

$O T>0.995(H Y)$ and $C T \leq 1.005(H T)$ and $C T \geq$ $0.995(H T)$

$O T>0.995(H Y)$ and $C T \leq 1.005(L T)$ and $C T \geq$ $0.995(L T)$

$O T<1.005(L Y)$ and $C T \leq 1.005(L T)$ and $C T \geq$ $0.995(L T)$

$O T<1.005(L Y)$ and $C T \leq 1.005(H T)$ and $C T \geq$ $0.995(H T)$

OT $=$ Open Today, $\mathrm{CT}=$ Close Today, LT $=$ Low Today, HT $=$ High Today, HY= High Yesterday, LY= Low Yesterday

When market observes $O T>H Y$ or $O T<L Y$, the market shows that performance of the equity has been affected considerably due to after-hour trading. For better grasp, a range has been developed of $\pm 0.5 \%$ for $H Y, L Y, H T$ 
and $L T$. "And" in between the equations indicates that all inequalities must be satisfied for the condition to exist. In condition (1), (3) \& (4) $O T>H Y$ indicates that an unexpected positive equity performance between two consecutive market days is witnessed. In condition (1) market shows that during the regular market timing after unexpected positive performance, the equity doesn't show any unexpected rise or fall and is traded normally showing effect of after-hour trading is not carry forwarded during next day of regular market timing but the market stabilises at the new price at opening. Condition (3) indicates that equity price continued with the unexpected positive equity performance indicating that price increase was inevitable and not in control of after-hour trading. Condition (4) indicates that the market rejected the equity's increase in price due to after-hour trading by falling down considerably.

Similarly for conditions (2), (5) \& (6) conclusion can be drawn in lines of conditions (1), (3) \& (4) respectively for an unexpected fall in price of equity. In condition (2), (5) \& (6) $O T<L Y$ indicates that an unexpected negative equity performance between two consecutive market days is witnessed. In condition (2) market shows that during the regular market timing after unexpected fall in price, the equity doesn't show any unexpected rise or fall and is traded normally showing effect of after-hour trading is not carry forwarded during next day of regular market timing but the market stabilises at the new price at opening. Condition (5) indicates that equity price continued with the unexpected negative equity performance indicating that price decrease was inevitable and not in control of after-hour trading. Condition (6) indicates that the market rejected the equity's fall in price due to after-hour trading by gaining considerably. Therefore, conditions (1) \& (2) are indication that market has accepted the unexpected price change occurring due to after-hours and stabilised with the changed price.

Number of day for each components equity price satisfying either condition 1 or condition 2 are recorded and divided by total number of market days ( 248 for 2017 \& 246 for 2018) to create different percentage range of $10 \%$ each from 0 to $40 \%$ as shown in Table $1 \&$ Table 2.

\section{Results}

Table 1 \& Table 2 shows Percentage of days in year 2017 and 2018 that satisfies condition $1 \& 2$ respectively. Overall sector index percentage is also shown. Components (\%) indicate the per cent of total market days satisfying the condition, by indicating the percentage range the equity falls in separately for both years. In Table 1, the each of the sector wise index except Nifty IT had more companies satisfying condition (1) at below $20 \%$ (inclusive of $0-10 \%$ $\& 10-20 \%)$ or less companies satisfying condition (1) at above $20 \%(20-40 \% \& 30-40 \%)$ of market days in year 2018 than 2017. Table 2 indicates: five index's (Nifty Energy, Nifty India Consumption, Nifty IT, Nifty MNC \& Nifty Service Sector) had more companies satisfy condition (2) for below $20 \%$ of market days in year 2018 than 2017; seven index's (Nifty Auto, Nifty Bank, Nifty Commodities, Nifty Financial Services, Nifty Infrastructure, Nifty Metal \& Nifty PSU Bank) had less companies satisfying condition (2) for below 20\% of market days in year 2018 than 2017. Four index's (Nifty FMCG, Nifty Media, Nifty Pharma \& Nifty Realty) had equal number of companies satisfying condition (2) for below 20\% of market days for year 2017 \& 2018.

Table 1: Percentage of days when index \& equity price satisfies condition 1 for year $2017 \& 2018$

\begin{tabular}{|c|c|c|c|c|c|c|c|c|c|c|c|c|}
\hline \multirow[t]{3}{*}{ S. No. } & \multirow{3}{*}{ Nifty Indices } & \multirow{2}{*}{\multicolumn{2}{|c|}{ Indice (\%) }} & \multirow{3}{*}{$\begin{array}{c}\text { Total } \\
\text { Components }\end{array}$} & \multicolumn{8}{|c|}{ Components (\%) } \\
\hline & & & & & \multicolumn{2}{|c|}{$0-10$} & \multicolumn{2}{|c|}{$10-20$} & \multicolumn{2}{|c|}{$20-30$} & \multicolumn{2}{|c|}{$30-40$} \\
\hline & & 2017 & 2018 & & 2017 & 2018 & 2017 & 2018 & 2017 & 2018 & 2017 & 2018 \\
\hline 1 & Nifty Auto & 28 & 30 & 16 & 0 & 0 & 0 & 1 & 15 & 14 & 1 & 1 \\
\hline 2 & Nifty Bank & 21 & 24 & 12 & 0 & 0 & 0 & 2 & 10 & 10 & 2 & 0 \\
\hline 3 & Nifty Commodities & 29 & 25 & 29 & 0 & 0 & 1 & 10 & 27 & 19 & 1 & 0 \\
\hline 4 & Nifty Energy & 30 & 24 & 10 & 0 & 0 & 0 & 3 & 9 & 7 & 1 & 0 \\
\hline 5 & Nifty Financial Services & 21 & 24 & 15 & 0 & 0 & 1 & 4 & 13 & 11 & 1 & 0 \\
\hline 6 & Nifty FMCG & 26 & 27 & 15 & 0 & 0 & 0 & 1 & 13 & 14 & 2 & 0 \\
\hline 7 & Nifty India Consumption & 23 & 26 & 30 & 0 & 0 & 6 & 10 & 21 & 19 & 3 & 1 \\
\hline 8 & Nifty Infrastructure & 23 & 24 & 25 & 0 & 0 & 4 & 16 & 19 & 9 & 2 & 0 \\
\hline 9 & Nifty IT & 25 & 28 & 10 & 0 & 0 & 3 & 2 & 7 & 8 & 0 & 0 \\
\hline 10 & Nifty Media & 32 & 27 & 15 & 0 & 2 & 5 & 8 & 10 & 5 & 0 & 0 \\
\hline 11 & Nifty Metal & 25 & 26 & 15 & 0 & 0 & 3 & 8 & 11 & 7 & 1 & 0 \\
\hline 12 & Nifty MNC & 25 & 29 & 30 & 0 & 0 & 6 & 7 & 23 & 23 & 1 & 0 \\
\hline 13 & Nifty Pharma & 33 & 24 & 10 & 0 & 0 & 0 & 3 & 10 & 7 & 0 & 0 \\
\hline 14 & Nifty PSU Bank & 30 & 23 & 12 & 0 & 0 & 4 & 7 & 8 & 5 & 0 & 0 \\
\hline 15 & Nifty Realty & 32 & 28 & 9 & 0 & 0 & 5 & 8 & 4 & 1 & 0 & 0 \\
\hline 16 & Nifty Service Sector & 17 & 20 & 31 & 0 & 0 & 3 & 9 & 26 & 22 & 2 & 0 \\
\hline
\end{tabular}


Table 2: Percentage of days when index \& equity price satisfies condition 2 for year $2017 \& 2018$

\begin{tabular}{|c|c|c|c|c|c|c|c|c|c|c|c|c|}
\hline \multirow[t]{3}{*}{ S. No. } & \multirow{3}{*}{ Nifty INDICES } & \multirow{2}{*}{\multicolumn{2}{|c|}{ INDICE (\%) }} & \multirow{3}{*}{$\begin{array}{c}\text { Total } \\
\text { Components }\end{array}$} & \multicolumn{8}{|c|}{ Components (\%) } \\
\hline & & & & & \multicolumn{2}{|c|}{ 0-10 } & \multicolumn{2}{|c|}{$10-20$} & \multicolumn{2}{|c|}{ 20-30 } & \multicolumn{2}{|c|}{$30-40$} \\
\hline & & 2017 & 2018 & & 2017 & 2018 & 2017 & 2018 & 2017 & 2018 & 2017 & 2018 \\
\hline 1 & Nifty Auto & 14 & 17 & 16 & 2 & 1 & 14 & 13 & 0 & 2 & 0 & 0 \\
\hline 2 & Nifty Bank & 15 & 20 & 12 & 0 & 0 & 11 & 10 & 1 & 2 & 0 & 0 \\
\hline 3 & Nifty Commodities & 17 & 17 & 29 & 2 & 0 & 26 & 26 & 1 & 3 & 0 & 0 \\
\hline 4 & Nifty Energy & 16 & 18 & 10 & 0 & 0 & 9 & 10 & 1 & 0 & 0 & 0 \\
\hline 5 & Nifty Financial Services & 16 & 17 & 15 & 0 & 0 & 14 & 13 & 1 & 2 & 0 & 0 \\
\hline 6 & Nifty FMCG & 15 & 20 & 15 & 1 & 1 & 13 & 13 & 1 & 1 & 0 & 0 \\
\hline 7 & Nifty India Consumption & 13 & 17 & 30 & 1 & 1 & 27 & 28 & 2 & 1 & 0 & 0 \\
\hline 8 & Nifty Infrastructure & 17 & 19 & 25 & 2 & 1 & 22 & 22 & 1 & 2 & 0 & 0 \\
\hline 9 & Nifty IT & 19 & 20 & 10 & 2 & 1 & 7 & 9 & 1 & 0 & 0 & 0 \\
\hline 10 & Nifty Media & 13 & 16 & 15 & 5 & 0 & 10 & 15 & 0 & 0 & 0 & 0 \\
\hline 11 & Nifty Metal & 17 & 20 & 15 & 5 & 0 & 10 & 14 & 0 & 1 & 0 & 0 \\
\hline 12 & Nifty MNC & 15 & 19 & 30 & 1 & 2 & 26 & 27 & 3 & 1 & 0 & 0 \\
\hline 13 & Nifty Pharma & 15 & 16 & 10 & 0 & 0 & 10 & 10 & 0 & 0 & 0 & 0 \\
\hline 14 & Nifty PSU Bank & 15 & 20 & 12 & 2 & 0 & 10 & 10 & 0 & 2 & 0 & 0 \\
\hline 15 & Nifty Realty & 9 & 16 & 9 & 4 & 1 & 5 & 8 & 0 & 0 & 0 & 0 \\
\hline 16 & Nifty Service Sector & 17 & 19 & 31 & 2 & 1 & 26 & 28 & 3 & 2 & 0 & 0 \\
\hline
\end{tabular}

\section{Conclusion}

Lesser the percentage of market days satisfying condition (1) \& (2) the lesser is the influence of after-hour trading on next day's regular market hours. Illustration in Table 1 indicates that condition (1) is satisfied for lesser percentage (below 20\%) of market days by more companies in all sectorwise indices (except NIFTY IT) in year 2018 than 2017. Hence indicating lesser after-hour trading influence in year 2018. However, only five index's out of sixteen satisfies condition (2) for lesser percentage (below 20\%) of market days by more companies in year 2018 than 2017. Hence not indicative of after-hour trading influence on next day's regular market hours. Hence the after-hour trading influence is decreased for year 2018 when the equity price increases unexpectedly (condition 1), but for unexpectedly falling equity price (condition 2) the market do not show unanimous trend to confirm after-hour trading influence.

A natural extension of this stream of literature is to examine the volatility of declining and increasing stocks. The non-information liquidity-driven trades increase volatility following stock price declines as is in accordance with result obtained for condition 2 , and the informed trades reduces volatility following stock price increase as in accordance with result obtained for condition 1 (Avramov et al., 2006).

Further, individual trades contribute more to price discovery after-hours than during normal market hours (Barclay \& Hendershott, 2003). Adverse selection costs are primary driver of large bid-ask spread during the after-hours period (Barclay \& Hendershott, 2004). Hence after-hour trading sets the appropriate price discovery as the above two studies by Barclay and Hendershott indicate that a greater proportion of individual trades are likely more informed after-hours than during market hours (Alldredge et al., 2012)

\section{References}

1. Alldredge D.M., Blau B.M., Brough T.J. Short selling after hours. J Econ Business 2012;64:439-451.

2. Anderson, Ronald C., Mansi, Sattar Reeb, David M. Founding family ownership and the agency cost of debt. J Financial Economics, 2003;92:205-22.

3. Avramov D., Chordia T., \& Goyal A. The impact of trades on daily volatility. Rev Financial Stud 2006;19:1241-77.

4. Barclay M. J., \& Hendershott T. Liquidity externalities and adverse selection: Evidence from trading after hours. J Finance 2003;59:681-710.

5. Barclay M. J., \& Hendershott T. Price discovery and trading after hours. Rev Financial Stud 2004;16:1041-73.

6. Murgia M., Pinna A., Gottardo P., \& Bosetti L. The impact of large orders in electronic markets. Int Rev Econ Finance 2019;59:174-92.

7. Tiwari A.K., Aye G.C., Gupta R. Stock market efficiency analysis using long spans of Data: A multifractal detrended fluctuation approach. Finance Research Letters, 2019;28:398411.

8. Zhang T., Gu G.F., Zhou W.F. Order imbalances and market efficiency: New evidence from Chinese stock market. Emerg Markets Rev 2019;38:458-67.

How to cite this article: Shah MJ, Shrivastava VA. Afterhour trading influence on price discovery of Indian equity market for year 2017 and 2018. J Manag Res Anal 2019;6(2):116-9.

Conflicts of Interest: Nil. 